\title{
Micronutrient concentration in potato clones with distinct physiological sensitivity to Al stress
}

\author{
Concentração de micronutrientes em clones de batata com distinta sensibilidade fisiológica ao estresse \\ de alumínio
}

\author{
Luciane Almeri Tabaldi ${ }^{I}$ Gabriel Y Castro ${ }^{\mathrm{I}}$ Denise Cargnelutti' ${ }^{\mathrm{II}}$ Etiane Caldeira Skrebsky ${ }^{\mathrm{I}}$ \\ Jamile Fabbrin Gonçalves ${ }^{I}$ Renata Rauber ${ }^{I}$ Liana Rossato $^{I}$ Maria Rosa Chitolina Schetinger ${ }^{I I}$ \\ Dílson Antônio Bisognin ${ }^{\mathrm{III}}$ Fernando Teixeira Nicoloso ${ }^{*}$
}

\section{ABSTRACT}

The objective of this study was to evaluate the effects of aluminum (Al) on the zinc ( $\mathrm{Zn})$, manganese ( $\mathrm{Mn})$, iron $(\mathrm{Fe})$ and copper $(\mathrm{Cu})$ concentrations in four potato clones (Macaca and Dakota Rose: both Al-sensitive clones; and SMIC148-A and Solanum microdontum: both Al-tolerantclones), grown in a nutrient solution ( $\mathrm{pH} 4.00$ ) with $0,50,100$, 150 and $200 \mathrm{mg} \mathrm{Al} \mathrm{L}^{-1}$. Root $\mathrm{Zn}$ and $\mathrm{Fe}$ concentrations decreased linearly with the increase of Al levels in Macaca, SMIC148-A and Dakota Rose and increased linearly in $\mathbf{S}$. microdontum. Shoot $\mathrm{Zn}$ concentration showed a quadratic relationship with $\mathrm{Al}$ in $\boldsymbol{S}$. microdontum and SMIC148-A, but a curvilinear response in Dakota Rose. Shoot Fe concentration showed a quadratic relationship with $\mathrm{Al}$ in $\mathrm{S}$. microdontum, SMIC148-A and Dakota Rose. Root Mn concentration decreased linearly in Macaca and SMIC148-A, and increased linearly in S. microdontum with Al levels. Mn concentration showed a quadratic relationship with Al in roots of Dakota Rose and in shoot of SMIC148-A, and increased curvilinearly with Al levels in shoot of Dakota Rose. In shoot, there was no alteration in $\mathrm{Zn}, \mathrm{Fe}$ and $\mathrm{Mn}$ in Macaca and Mn concentration in $\mathbf{S}$. microdontum. Roots and shoot $\mathrm{Cu}$ concentration increased linearly in Dakota Rose, and showed quadratic relationship with Al in Macaca. Roots Cu concentration showed a quadratic relationship with Al levels in S. microdontum and SMIC148-A. Shoot $\mathrm{Cu}$ concentration increased linearly in $\mathrm{S}$. microdontum, and decreased linearly in SMIC148-A. Therefore, the excessive Al accumulation affected the uptake and distribution of $\mathrm{Zn}, \mathrm{Fe}$, $\mathrm{Mn}$ and $\mathrm{Cu}$ in roots and shoot of potato clones.The response of shoot $\mathrm{Cu}$ concentration to $\mathrm{Al}$ was less altered in the Al-tolerant clones than was in Al-sensitive clones. Aluminum tolerance in S. microdontum may be connected with greater levels of $\mathrm{Zn}, \mathrm{Fe}$ and $\mathrm{Mn}$ in the roots.

Key words: Solanum tuberosum, Solanum microdontum, zinc, manganese, iron, copper.

\section{RESUMO}

O objetivo deste estudo foi caracterizar o efeito do alumínio (Al) na concentração de zinco ( $\mathrm{Zn})$, manganês ( $\mathrm{Mn})$, ferro ( $\mathrm{Fe}$ ) e cobre ( $\mathrm{Cu}$ ) em quatro clones de batata (Macaca e Dakota Rose: sensíveis ao Al; e SMIC148-A e Solanum microdontum: tolerantes ao Al) crescendo em solução nutritiva (pH 4,0) com 0, 50, 100, 150 e 200mg Al L-1. A concentração de $\mathrm{Zn}$ e Fe em raízes diminuiu linearmente com o aumento dos níveis de Al nos clones Macaca, SMIC148-A e Dakota Rose e aumentou linearmente em $\boldsymbol{S}$. microdontum. Na parte aérea, a concentração de $\mathrm{Zn}$ mostrou resposta quadrática ao $\mathrm{Al} \mathrm{em} \mathrm{S}$. microdontum e SMIC148-A, enquanto no clone Dakota Rose houve uma resposta cúbica. Nos clones $S$. microdontum, SMIC148-A e Dakota Rose, a concentração de Fe mostrou resposta quadrática ao $\mathrm{Al}$. A concentração de $\mathrm{Mn}$ em raízes diminuiu linearmente em relação ao Al nos clones Macaca e SMIC148-A e aumentou linearmente em S. microdontum. Para Dakota Rose e SMIC148-A, a concentração de Mn mostrou uma resposta quadrática em relação ao $\mathrm{Al}$ em raízes e parte aérea. A concentração de Mn na parte aérea aumentou de forma cúbica com os níveis de Al no clone Dakota Rose. Na parte aérea, não houve alteração na concentração de $\mathrm{Zn}$ e Fe na Macaca e de Mn nos clones Macaca e S. microdontum. Em raízes e na parte aérea, a concentração de Cu aumentou linearmente no clone Dakota Rose e mostrou resposta quadrática no clone Macaca. A concentração de Cu mostrou resposta quadrática com os níveis de Al em raízes dos clones $S$. microdontum e SMIC148-A. Na parte aérea, a concentração de $\mathrm{Cu}$ aumentou linearmente no clone $\mathrm{S}$. microdontum $e$ diminuiu linearmente no clone SMIC148-A com o aumento nos níveis de Al. Portanto, a acumulação excessiva de Al afetou negativamente a absorção e a distribuição de $\mathrm{Zn}, \mathrm{Fe}, \mathrm{Mn}$ e $\mathrm{Cu}$ nas raízes e na parte aérea dos clones de batata. A resposta da concentração de Cu na parte aérea ao Al foi menos alterada

IDepartamento de Biologia, Centro de Ciências Naturais e Exatas (CCNE), Universidade Federal de Santa Maria (UFSM), 97105900, Santa Maria, RS, Brasil. E-mail: ftnicoloso@yahoo.com. Autor para correspondência.

IIDepartamento de Química, CCNE, UFSM, Santa Maria, RS, Brasil.

IIIDepartamento de Fitotecnia, Centro de Ciências Rurais (CCR), UFSM, Santa Maria, RS, Brasil. 
nos clones Al-tolerantes que naqueles Al-sensíveis. A tolerância ao Al em S. microdontum pode estar conectada com os maiores níveis de $\mathrm{Zn}$, Fe e Mn nas raízes.

Palavras-chave: Solanum tuberosum, Solanum microdontum, zinco, manganês, ferro, cobre.

\section{INTRODUCTION}

The mineral nutrient status of plants is directly related to their growth and productivity. Micronutrients are basic requirements for plant growth and development and their status is controlled by their genetically fixed nutrient uptake potential, the nutrient availability in the soil, and other environmental factors (MENGEL \& KIRKBY, 2001). On the other hand, availability of most micronutrients depends, amongst other factors, on the $\mathrm{pH}$ of the soil solution, as well as the nature of binding sites on organic and inorganic particle surfaces (TUNA et al., 2008). Trace elements are adsorbed by inorganic constituents such as iron (Fe) and aluminum (Al) oxides and form complexes with organic matter (OMIL et al., 2007). Environmental variation of nutrient availability is expected to result in changes in plant physiology and morphology, and consequently in changes in the yield.

Acid soils are found throughout the world. It is estimated that about $40 \%$ of the world's arable soils and $12 \%$ of the land in crop production have a $\mathrm{pH}$ below 5.5 (VON UEXKÜLL \& MUTERT, 1995). Moreover, soil acidification is increasing world-wide. These soils are often characterized by the reduced availability of several nutrients (FOY, 1992). In fact, soil acidification could bring about many other changes in the physical and chemical properties of the soil, which in turn affect plant growth and development.

In acid soil, some nutrients, such as $\mathrm{P}, \mathrm{Ca}$, and $\mathrm{Mg}$, may be deficient, whereas others, such as $\mathrm{Mn}$ and $\mathrm{B}$, could be toxic to plants. In addition, the continuing acidification of soils with the low buffering capacity leads to an increase of the Al mobilization in the environment and may be potentially hazardous to the all terrestrial and aquatic systems (MATÚS et al., 2006). These effects are further complicated by interactions of $\mathrm{Al}$ with other ions in different plant genotypes and under stress conditions (FOY, 1992). Although Al is the most abundant metal in the Earth's crust, it is nonessential for plants. Despite Al occurs in various chemical species, $\mathrm{Al}^{3+}$ is regarded the most toxic of the soluble forms of Al (PARKER et al., 1988). The $\mathrm{Al}$ cation $\mathrm{Al}^{3+}$ is toxic to many plants at micromolar concentrations, affecting primarily the normal functioning of roots. The rapid inhibition of Al-mediated root growth (RYAN et al., 1993) results in poor nutrient and water acquisition and transport, consequently leads to nutrient deficiencies and decreased crop yields (KOCHIAN, 1995). Aluminum toxicity may be manifested as a deficiency of essential nutrients like $\mathrm{Ca}, \mathrm{Mg}, \mathrm{Fe}, \mathrm{Zn}$ or Mo; decreased availability of $\mathrm{P}$ or as toxicity of $\mathrm{Mn}$ and $\mathrm{H}^{+}$(SCHÖLL et al., 2005; GUO et al., 2007). Aluminum at high levels competes with cationic (mono or bivalents) ions for absorption sites in channels or transporters (KOCHIAN, 1995).

The interference of Al with uptake, transport and utilization efficiency of most of the mineral elements has been well documented (McCOLL et al., 1991; GUO et al., 2007). On the other hand, there is a lack of studies connecting the effects of $\mathrm{Al}$ on the uptake and transport of micronutrients in plants. In addition, GIANNAKOULA et al. (2008) suggested that higher levels of mineral nutrients may be connected with Al tolerance. In our previous research (TABALDI et al., 2007) was demonstrated that toxic concentrations of $\mathrm{Al}$ in nutrient solution caused oxidative stress in four potato clones, as evidenced by increased $\mathrm{H}_{2} \mathrm{O}_{2}$ formation, lipid peroxidation and oxidation of proteins in roots and shoots, mainly in Al-sensitive clones (Macaca and Dakota Rose). This study suggested that the reduced growth (length of roots and shoots) in Alsensitive clones exposed to toxic levels of Al might be induced by an enhanced production of toxic oxigen species and subsequent lipid peroxidation. Moreover, it was possible to observe that Al-tolerant clones (SMIC148-A and S. microdontum) developed some defense mechanisms agaisnt oxidative stress. Utilizing the same plant biomass obtained by TABALDI et al. (2007) the present work aimed to analyze the influence of Al exposure in nutrient solution on the micronutrients concentration in roots and shoot of the same four potato clones.

\section{MATERIAL AND METHODS}

Three adapted $(2 \mathrm{n}=4 \mathrm{x}=48)$ clones (Macaca, SMIC148-A and Dakota Rose) and one wild species $(2 \mathrm{n}=2 \mathrm{x}=24)$ clone (PI595511-5 of Solanum microdontum) were evaluated. The $S$. microdontum was identified as highly resistant to Phytophora infestans (BISOGNIN et al., 2005) and has been used in our breeding program. This clone will be referred to as S. microdontum. Tissue culture plantlets were obtained from the Potato Breeding and Genetics Program, Federal University of Santa Maria, Brazil. Nodal segments (1.0 cm long) were micropropagated in MS medium (MURASHIGE \& SKOOG, 1962), supplemented with $30 \mathrm{~g} \mathrm{~L}^{-1}$ of sucrose, $0.1 \mathrm{~g} \mathrm{~L}^{-1}$ of myo-inositol and $6 \mathrm{~g} \mathrm{~L}^{-1}$ of agar. 
Twenty-day-old plantlets from in vitro culture were transferred into plastic boxes (10L) filled with aerated full nutrient solution of low ionic strength. The nutrient solution had the following composition (in $\mu \mathrm{M}$ ): 6090.5 of $\mathrm{N} ; 974.3$ of Mg; 5229.5 of Cl; 2679.2 of $\mathrm{K} ; 2436.2$ of Ca; 359.9 of S; 0.47 of Cu; 2.00 of $\mathrm{Mn}$; 1.99 of $\mathrm{Zn} ; 0.17$ of $\mathrm{Ni} ; 24.97$ of B; 0.52 of Mo; 47.99 of Fe ( $\left.\mathrm{FeSO}_{4} / \mathrm{Na}-\mathrm{EDTA}\right)$. Treatments consisted of the addition of $0,50,100,150$ or $200 \mathrm{mg} \mathrm{Al} \mathrm{L}^{-1}$ as $\mathrm{AlCl}_{3} \cdot 6 \mathrm{H}_{2} \mathrm{O}$. The solutions $\mathrm{pH}$ was adjusted daily to $4.0 \pm 0.1$ by titration with $\mathrm{HCl}$ or $\mathrm{NaOH}$ solutions of $0.1 \mathrm{M}$. Both in vitro and ex vitro cultured plants were grown in a growth chamber at $25 \pm 2^{\circ} \mathrm{C}$ on a $16 / 8$-h light/dark cycle with $35 \mu \mathrm{mol} \mathrm{m} \mathrm{m}^{-2} \mathrm{~s}^{-1}$ of irradiance. Aluminum-treated plantlets remained in each treatment for seven days. At harvest, the plantlets were divided into shoot and roots. Roots were rinsed twice with distilled water. Subsequently, micronutrients concentrations were determined.

After Al treatment, samples (roots and shoot) were dried at $60^{\circ} \mathrm{C}$ until reaching a constant weight. The dried tissue were weighed and ground into a fine powder before of the nitric-percloric digestion. Micronutrients concentrations were determined by atomic absorption spectrometry.

All data were analyzed by ANOVA procedures. The effects of $\mathrm{Al}$ on micronutrients concentration in roots and shoot of potato plantlets were quantified using regression analysis with the SOC statistic package (Software Científico: NTIA/ EMBRAPA). Coefficients were included in a regression equation when their values were significant $(\mathrm{P}<0.05)$.

\section{RESULTS AND DISCUSSION}

Plants require an adequate supply of micronutrients for their normal physiological and biochemical functions. Deficiencies of essential micronutrients induce abnormal pigmentation, size, and shape of plant tissues, reduce leaf photosynthetic rates, and lead to various detrimental conditions (MASONI et al., 1996). In our previous study (TABALDI et al., 2007 ), based on relative root growth, it was demonstrated that $\boldsymbol{S}$. microdontum and SMIC148-A are Al-tolerant clones, whereas Macaca and Dakota Rose are Al-sensitive clones. It was proposed that the reduced growth in $\mathrm{Al}$-sensitive clones of potato exposed to toxic levels of $\mathrm{Al}$ might be induced by an enhanced production of toxic oxygen species and subsequent lipid peroxidation. In addition, regression analysis showed that the concentration of Al in both the roots and shoot of these clones increased linearly with the increase of $\mathrm{Al}$ levels, and the increase in tissue $\mathrm{Al}$ was much steeper for Macaca and SMIC148-A clones. However, the maximum concentration of $\mathrm{Al}$ in roots and shoot was 49,300 and $17,900 \mathrm{mg} \mathrm{kg}^{-1}$, as respectively found in Dakota Rose clone at $200 \mathrm{mg} \mathrm{Al} \mathrm{L}^{-1}$. Moreover, it was possible to observe that Al-tolerant plants developed some defense mechanisms against oxidative stress.

In this study, the concentration of some micronutrients in the tissue of roots and shoots of four potato clones was examined after seven days of $\mathrm{Al}$ exposure. A micronutrient- and organ-dependent response to Al toxicity was observed in all potato clones. Micronutrients concentration was higher in roots than in shoot of all potato clones tested, suggesting that more micronutrients were retained in the roots and lower amounts were transported to the shoot. Regression analysis showed that the concentration of zinc $(\mathrm{Zn})$ decreased linearly with the increase of Al levels in roots of Macaca, SMIC148-A and Dakota Rose clones (Figure 1A). This result is similar to those reported by KOLAWOLE et al. (2000) and JEMO et al. (2007), who observed reduction in nutrient acquisition in cowpea genotypes exposed to Al. High concentrations of Al in the substrate decreased the uptake of $\mathrm{Ca}, \mathrm{K}, \mathrm{P}, \mathrm{Fe}$, and $\mathrm{Zn}$ in birch seedlings (Betula pendula Roth.), limiting the growth of roots and shoot (BOJARCZUK et al., 2002).

As it was observed for $\mathrm{Zn}$ concentration, root iron $(\mathrm{Fe})$ concentration decreased linearly with the increase of Al levels in Macaca, SMIC148-A and Dakota Rose clones (Figure 1C). At 200mg Al L-1 , root Fe concentration decreased by about $20 \%, 47 \%$ and $30 \%$, in Macaca, SMIC148-A and Dakota Rose clones, respectively, when compared to the control. Metalmetal interactions may occur when cations compete for negatively charged binding sites at the cell surface (KINRAIDE et al., 1992). Since the cell wall is the major site of metal accumulation (KOCHIAN, 1995) and provides the bulk of charged surfaces in the apoplasm, the metal-metal interations should affect total metal accumulation. These data might indicate a direct competition between $\mathrm{Al}$ and essential nutrients for the same uptake site. Aluminum at high levels competes with cationics (mono or bivalents) ions for absorption sites in channels or transporters (KOCHIAN, 1995). This competition may reduce the ion absorption and utilization. In addition, Al ions may bind to the phospholipids heads of the plasma membrane, alter the lipid-protein interaction, and modify the activity of the transporters (SUHAYDA \& HAUG, 1986). Another possibility is that Al binds directly to the transport proteins, thereby impairing their function (SCHROEDER, 1988). 

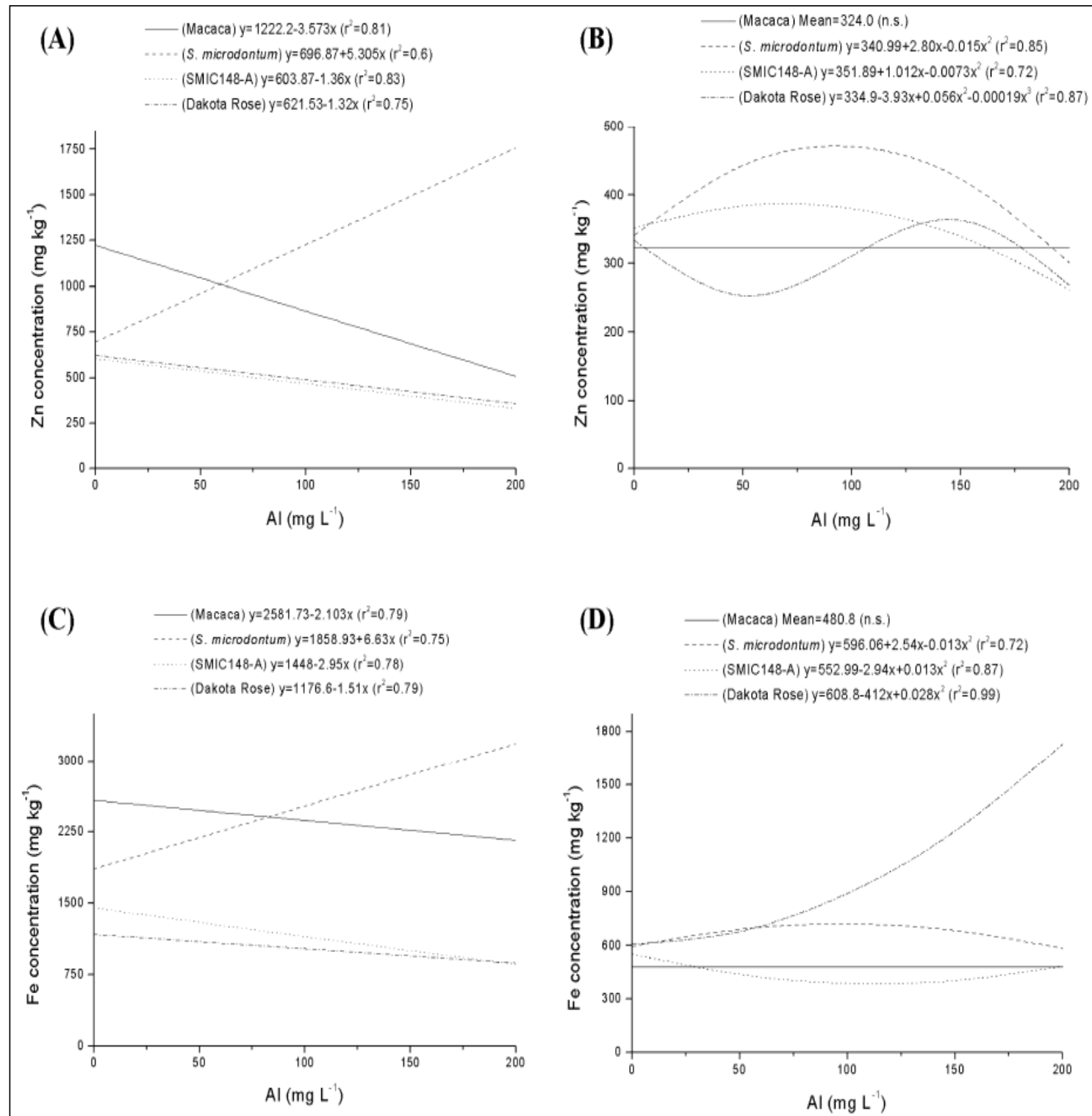

Figure 1 - Effect of increasing Al concentration on the zinc ( $\mathrm{Zn})$ of roots $(\mathrm{A})$ and shoot $(\mathrm{B})$, and iron (Fe) concentration of roots (C) and shoot (D) of potato clones, Macaca, S. microdontum, SMIC148-A and Dakota Rose, submitted to increasing $\mathrm{Al}$ concentration for 7 days. n.s.: not significant.

Roots $\mathrm{Zn}$ and Fe concentrations increased linearly with the increase of Al levels in the $\boldsymbol{S}$. microdontum clone (Figures $1 \mathrm{~A}$ and $1 \mathrm{C}$, respectively). In this study, $\boldsymbol{S}$. microdontum clone had greater concentrations of most micronutrients analyzed. Therefore, as this potato clone is Al-tolerant (TABALDI et al., 2007) it seems that the Al levels tested was not enough to cause severe alteration in the metabolism. Thus, higher levels of mineral nutrients may be connected with Al tolerance, as suggested by GIANNAKOULA et al. (2008). Shoot Zn concentration showed a quadratic relationship in the $S$. microdontum and SMIC148-A clones, increasing in intermediary Al levels (Figure 1B). In Dakota Rose clone, shoot Zn concentration showed a curvilinear response, decreasing at approximately $50 \mathrm{mg} \mathrm{Al} \mathrm{L}^{-1}$ and increasing at approximately $150 \mathrm{mg} \mathrm{Al} \mathrm{L}^{-1}$ (Figure 1B). In SMIC148A clone, shoot $\mathrm{Fe}$ concentration decreased between Al levels of approximately 50 and $150 \mathrm{mg} \mathrm{Al} \mathrm{L}^{-1}$ and showed a quadratic increase in Dakota Rose clone. On the other hand, shoot Fe concentration slightly increased at Al levels between approximately 50 and $100 \mathrm{mg} \mathrm{Al} \mathrm{L}^{-1}$ in the $\boldsymbol{S}$. microdontum clone.

Roots manganese $(\mathrm{Mn})$ concentration decreased linearly in both Macaca and SMIC148-A clones, and increased linearly with the increase of $\mathrm{Al}$ 
levels in S. microdontum clone (Figure 2A). However, in Dakota Rose clone, Mn concentration showed a quadratic relationship to $\mathrm{Al}$ supply, decreasing at levels between approximately 50 and $100 \mathrm{mg} \mathrm{Al} \mathrm{L}^{-1}$ and increasing at $200 \mathrm{mg} \mathrm{Al} \mathrm{L}^{-1}$. Shoot $\mathrm{Mn}$ concentration showed a quadratic relationship with $\mathrm{Al}$ levels in the SMIC148-A clone (Figure 2B), decreasing at levels between approximately 50 and $100 \mathrm{mg} \mathrm{Al} \mathrm{L}^{-1}$ and increasing at $200 \mathrm{mg} \mathrm{Al} \mathrm{L}^{-1}$. For Dakota Rose clone, shoot $\mathrm{Mn}$ concentration showed a curvilinear response to $\mathrm{Al}$ supply, increasing at levels between approximately 100 and $150 \mathrm{mg} \mathrm{Al} \mathrm{L}^{-1}$, while in the $\boldsymbol{S}$. microdontum clone there was no alteration in Mn concentration.
There was no alteration in shoot $\mathrm{Zn}$ (Figure 1B), Fe (Figure 1D) and Mn (Figure 2B) concentration in Macaca clone. However, in the previous study (TABALDI et al., 2007), shoot growth in this clone decreased linearly with the increase of Al levels. Therefore, the interference of $\mathrm{Al}$ in the root growth and in the absorption and transport of water and other nutrients may have brought about lower shoot growth.

Copper $(\mathrm{Cu})$ is an essential plant micronutrient playing an important role in both photosynthetic and respiratory electron transport, being a cofactor for many enzymes (OWEN, 1982). However, when present in elevated concentrations it

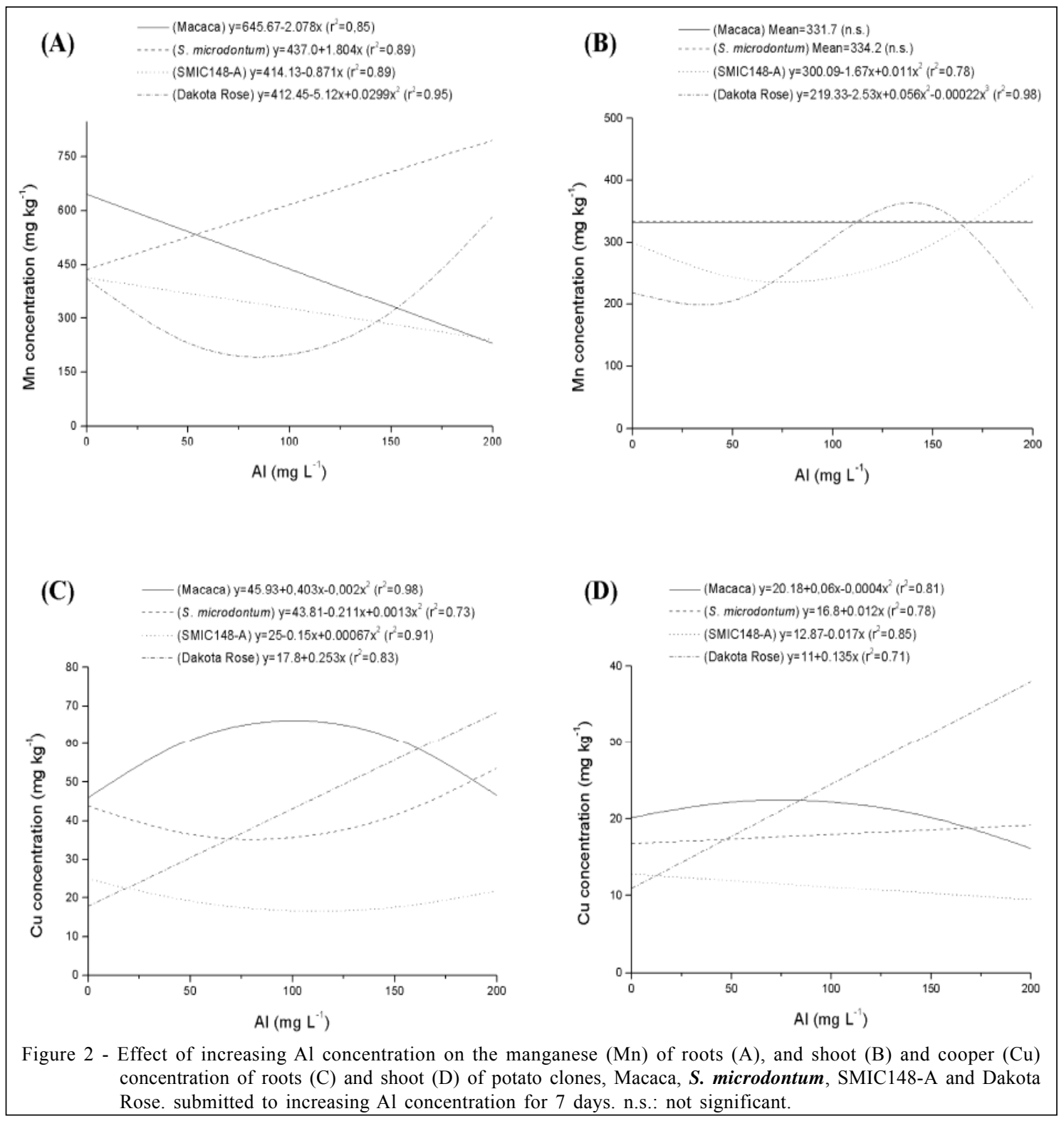

Ciência Rural, v.39, n.2, mar-abr, 2009. 
affects different parameters of plant metabolism, such as dry mass accumulation (ALI et al., 2002; ZHENG et al., 2004), chlorophyll (LOU et al., 2004), and water content (BURZYNSKI \& KLOBUS, 2004) and the balance in macro- and micronutrient levels (ALI et al., 2002; BERNAL et al., 2007). Being a redox active metal, $\mathrm{Cu}$ generates reactive oxygen species (ROS) by Fenton reaction, which may result in oxidative stress leading to peroxidation of membrane lipids (STOHS \& BAGCHI, 1995). The response of root $\mathrm{Cu}$ concentration in the Dakota Rose clone to $\mathrm{Al}$ levels was linear and positive (Figure 2C), whereas in Macaca it increased only at levels between approximately 50 and $150 \mathrm{mg} \mathrm{Al} \mathrm{L}^{-1}$. By contrast, in both Al-tolerant clones, root $\mathrm{Cu}$ concentration showed in general an inverse relationship with the increase of Al levels, with exception of the $\boldsymbol{S}$. microdontum clone that showed increased $\mathrm{Cu}$ concentration at $200 \mathrm{mg} \mathrm{Al} \mathrm{L}^{-1}$ when compared to the control (Figure 2C). Shoot $\mathrm{Cu}$ concentration in the Dakota Rose clone increased linearly with the increase of Al levels (Figure 2D), while in the Macaca clone it slightly increased at Al levels between approximately 50 and $100 \mathrm{mg} \mathrm{Al} \mathrm{L}^{-1}$. The response of shoot $\mathrm{Cu}$ concentration in the $\boldsymbol{S}$. microdontum clone to Al levels was linear and positive (Figure 2D), while in SMIC148-A it was linear and negative (Figure 2D). However, for these two Al-tolerant clones shoot $\mathrm{Cu}$ concentration was less altered than that of Al-sensitive clones. Therefore, the increase in tissue $\mathrm{Cu}$ concentration observed in the potato clones exposed to Al might have caused disturbance in the metabolism, and hence to plant growth and development, mainly in the Al-sensitive clones.

Plants vary in sensitivity to toxic compounds in the soil. Many studies showed that the sensitivity depends on many factors, such as physicochemical properties of the soil, concentration of organic matter and nutrients, but primarily on soil $\mathrm{pH}$ (RENGEL, 1996). Aluminum is widespread in the Earth's crust and its availability to plants increases with decreasing $\mathrm{pH}$ of the soil (BOUDOT et al., 1994). The toxic $\mathrm{Al}$ ions present in the substrate can damage root cells, which become inefficient in absorption and translocation of both nutrients and water (MOSSORPIETRASZEWSKA et al., 1997), blocking their participation in important metabolic processes, such as photosynthesis and respiration (RENGEL, 1996).

Therefore, in the present study, the excessive Al accumulation observed could have affected the rate of uptake and distribution of certain micronutrients in roots and shoot of potato clones, and consequently would be responsible for mineral deficiencies/imbalance and depression of the plant growth. Selection of plants tolerant to toxic ions contained in the soil can enable more effective management of degraded habitats.

\section{CONCLUSIONS}

The excessive $\mathrm{Al}$ accumulation affected the rate of uptake and distribution of $\mathrm{Zn}, \mathrm{Fe}, \mathrm{Mn}$ and $\mathrm{Cu}$ in roots and shoot of potato clones and the response of shoot $\mathrm{Cu}$ concentration to $\mathrm{Al}$ was less altered in the Al-tolerant clones than was in Al-sensitive clones. Aluminum tolerance in $\boldsymbol{S}$. microdontum may be connected with greater levels of $\mathrm{Zn}, \mathrm{Fe}$ and $\mathrm{Mn}$ in the roots.

\section{ACKNOWLEDGEMENTS}

The authors thank the Coordenação e Aperfeiçoamento de Pessoal de Nível Superior (CAPES), Conselho Nacional de Desenvolvimento Científico e Tecnológico (CNPq), and Fundação de Amparo à Pesquisa de Estado do Rio Grande do Sul (FAPERGS) for the research fellowships

\section{REFERENCES}

ALI, N.A. et al. Tolerance and bioaccumulation of copper in Phragmites australis and Zea mays. Plant and Soil, The Hague, v.239, n.1, p.103-111, 2002.

BERNAL, M. et al. Foliar and root $\mathrm{Cu}$ supply affect differently $\mathrm{Fe}$ - and $\mathrm{Zn}$-uptake and photosynthetic activity in soybean plants. Environmental and Experiemntal Botany, Elmsford, v.60, n.2, p.145-150, 2007.

BISOGNIN, D.A. et al. Mapping late blight resistance in Solanum microdontum Bitter. Crop Science, Madison, v.45, n. 1, p.340-345, 2005.

BOJARCZUK, K. et al. Effect of polluted and fertilization on growth and physiology of silver birch (Betula pendula Roth.) seedlings. Polish Journal of Environmental Studies, Olsztyn, v.11, n.5, p.483-492, 2002.

BOUDOT, J.P. et al. Aluminum toxicity in declining forests: a general overview with a seasonal assessment in a silver fir forest in the Vosges mountains (France). Annales of Forest Science, Champenoux, v.51, n.1, p.27-51, 1994.

BURZYNSKI, M.; KLOBUS, G. Changes of photosynthetic parameters in cucumber leaves under $\mathrm{Cu}, \mathrm{Cd}$ and $\mathrm{Pb}$ stress. Photosynthetica, Prague, v.42, n.4, p.505-510, 2004.

FOY, C.D. Soil chemical factors limiting plant root growth. Advances in Soil Science, Beltsville, v.19, n.1, p.97-149, 1992.

GIANNAKOULA, A. et al. Aluminum tolerance in maize is correlated with increased levels of mineral nutrients, carbohydrates and praline, and decreased levels of lipid peroxidation and Al accumulation. Journal of Plant Physiology, Stuttgart, v.165, n.4, p.385-396, 2008. 
GUO, T.R. et al. Physiological changes in barley plants under combined toxicity of aluminum, copper and cadmium. Colloids and Surfaces B: Biointerfaces, Amsterdam, v.57, n.2, p.182$188,2007$.

JEMO, M. et al. Aluminum resistance of cowpea as affected by phosphorus-deficiency stress. Journal of Plant Physiology, Stuttgart, v.164, n.4, p.442-451, 2007.

KINRAIDE, T.B. et al. Interactive effects of $\mathrm{A}^{3+}, \mathrm{H}^{+}$, and other cations on root elongation considered in terms of cellsurface electrical potential. Plant Physiology, Minneapolis, v.99, n.4, p.1461-1468, 1992.

KOCHIAN, L.V. Cellular mechanisms of aluminum toxicity and resistance in plants. Annual Review of Plant Physiology and Plant Molecular Biology, Palo Alto, v.46, n.1, p.237260, 1995 .

KOLAWOLE, G.O. et al. Differential response of cowpea lines to aluminum and phosphorus application. Journal of Plant Nutrition, New York, v.23, n.6, p.731-40, 2000.

LOU, L-Q. et al. The copper tolerance mechanisms of Elsholtzia haichowensis, a plant from copper-enriched soils. Environmental and Experimental Botany, Elmsford, v.51, n.2, p.111-120, 2004.

MASONI, A. et al. Special properties of leaves deficient in iron, sulfur, magnesium, and manganese. Agronomy Journal, Madison, v.88, n.5, p.937-943, 1996.

MATÚS, P. et al. Free aluminium extraction from various reference materials and acid soils with relation to plant availability. Talanta, London, v.70, n.5, p.996-1005, 2006.

McCOLL, J.G. et al. Aluminium effect on six wheat cultivars in Kenyan soils. Communications in Soil Science and Plant Analysis, New York, v.22, n.6, p.1701-1719, 1991.

MENGEL, K.; KIRKBY, E.A. Principles of plant nutrition. 5.ed. Kluwer: Dordrecht, 2001. 849p.

MOSSOR-PIETRASZEWSKA, T. et al. The influence of aluminium ions on activity changes of some dehydrogenases and aminotransferases in yellow lupine. Biologica Bulletin of Poznan, Poznan, v.34, n.1, p.47-48, 1997.

MURASHIGE, T.; SKOOG, F. A revised medium for rapid growth and bioassays with tobacco tissue culture. Plant Physiology, Minneapolis, v.15, n.2, p.473-497, 1962.
OMIL, B. et al. Trace elements in soils and plants in temperate forest plantations subjected to single and multiple applications of mixed wood ash. Science of the Total Environment, Michigan, v.381, n.1-3, p.157-168, 2007.

OWEN, C. Biochemical aspects of copper. Noyes: Park Ridge, NJ, 1982. 176p.

PARKER, D.R. et al. Aluminum speciation and phytotoxicity in dilute hydroxy-aluminum solutions. Soil Science Society of America Journal, Madison, v.52, n.2, p.438-444, 1988.

RENGEL, Z. Uptake of aluminium by plant cells. New Phytologist, Cambridge, v.134, n.3, p.389, 1996.

RYAN, P.R. et al. Aluminum toxicity in roots: an investigation of spatial sensitivity and the role of the root cap. Journal of Experimental Botany, Oxford, v.44, n.2, p.437-446, 1993.

SCHROEDER, J.I. $\mathrm{K}^{+}$transport properties of $\mathrm{K}^{+}$channels in the plasma membrane of Vicia faba guard cells. Journal of General Physiology, New York, v.92, n.4, p.667-683, 1988.

SCHÖLL, L. et al. Effects of ectomycorrhizal colonization on the uptake of $\mathrm{Ca}, \mathrm{Mg}$ and $\mathrm{Al}$ by Pinnus sylvestris under aluminum toxicity. Forest Ecology and Management, Melbourne, v. 215 , n. $1-3$, p.352-360, 2005

STOHS, S.J.; BAGCHI, D. Oxidative mechanisms in the toxicity of metal ions. Free Radical Biology and Medicine, New York, v.18, n.2, p.321-336, 1995.

SUHAYDA, C.G.; HAUG, A. Organic acids reduce aluminum toxicity in maize root membranes. Physiologia Plantarum, Copenhagen, v.68, n.2, p.189-195, 1986

TABALDI, L.A. et al. Physiological and oxidative stress responses of four potato clones to aluminum in nutrient solution. Brazilian Journal of Plant Physiology, Piracicaba, v.19, n.3, p.211-222, 2007.

TUNA, A.L. et al. The combined effects of gibberellic acid and salinity on some antioxidant enzyme activities, plant growth parameters and nutritional status in maize plants Environmental and Experimental Botany, Elmsford, v.62, n.1, p.1-9, 2008.

VON UEXKÜLL, H.R.; MUTERT, E. Global extent, development and economic impact of acid soils. Plant and Soil, The Hague, v.171, n.1, p.11-15, 1995.

ZHENG, Y. et al. Response to copper toxicity for three ornamental crops in solution culture. HortScience, Alexandria, v.39, n.6, p.1116-1120, 2004. 